\title{
Engineering Klebsiella sp. 601 multicopper oxidase enhances the catalytic efficiency towards phenolic substrates
}

\author{
Yadong Li ${ }^{\dagger}$, Zijun Gong ${ }^{\dagger}$, Xin Li, Yang Li and Xing-Guo Wang
}

\begin{abstract}
Background: Structural comparison between bacterial $\mathrm{CueO}$ and fungal laccases has suggested that a charged residue Glu (E106) in CueO replaces the corresponding residue Phe in fungal laccases at the gate of the tunnel connecting type II copper to the protein surface and an extra $\alpha$-helix (L351-G378) near the type I copper site covers the substrate binding pocket and might compromise the electron transfer from substrate to type I copper. To test this hypothesis, several mutants were made in Klebsiella sp. 601 multicopper oxidase, which is highly homologous to E. coli CueO with a similarity of $90 \%$ and an identity of $78 \%$.

Results: The E106F mutant gave smaller $K_{m}$ (2.4-7fold) and $k_{\text {cat }}(1-4.4$ fold) values for all three substrates DMP, ABTS and SGZ as compared with those for the wild-type enzyme. Its slightly larger $k_{\text {cat }} / K_{m}$ values for three substrates mainly come from the decreased $K_{m}$. Deleting $\alpha$-helix (L351-G378) resulted in the formation of inactive inclusion body when the mutant ${ }^{\Delta} \alpha 351-378$ was expressed in E. coli. Another mutant $\alpha 351-380 \mathrm{M}$ was then made via substitution of seven amino acid residues in the $\alpha$-helix (L351-G378) region. The $\alpha 351-380 \mathrm{M}$ mutant was active, and displayed a far-UV CD spectrum markedly different from that for wild-type enzyme. Kinetic studies showed the a351-380M mutant gave very low $K_{m}$ values for DMP, ABTS and SGZ, 4.5-, 1.9- and 7-fold less than those for the wild type. In addition, $k_{\text {cat }} / K_{m}$ values were increased, 9.4-fold for DMP, similar for ABTS and 3-fold for SGZ.

Conclusion: The Glu residue at position 106 appears not to be the only factor affecting the copper binding, and it may also play a role in maintaining enzyme conformation. The $\alpha$-helix (L351-G378) may not only block access to the type I copper site but also play a role in substrate specificities of bacterial MCOs. The a351-380M mutant catalyzing oxidation of the phenolic substrate DMP effectively would be very useful in green chemistry.
\end{abstract}

\section{Background}

Multicopper oxidases (MCOs) contain a multiple copper center, and catalyze the oxidation of a variety of substrates along with the four-electron reduction of dioxygen to water [1]. Laccases are a member of family [2], and are widely distributed in plants and fungi $[2,3]$. Owing to their involvement in the transformation of a wide variety of phenolic compounds, including the polymeric lignin and humic substrates, fungal laccases attract considerable attention. It has been reported that laccases show multiple functions, including lignin degradation, pigmentation, lignin biosynthesis and pathogenesis in fungi, and, in addition to their organic substrate,

\footnotetext{
* Correspondence: xgw569@hotmail.com

+ Contributed equally

Faculty of Life Sciences, Hubei Unversity, Wuhan 430062 China
}

require only molecular oxygen for catalysis, which makes them suitable for biotechnological application [4-11].

It has been reported recently that bacterial MCOs display laccase-like functions [12-15]. Several bacterial laccases were purified and crystallized, and two crystal structures, of B. subtilis CotA and E. coli $\mathrm{CueO}$, were also determined at high resolution [16-18]. The structure of CueO, similar to that of CotA, is composed of three repeated pseudoazurin domains with the type I copper site in domain 3 and a trinuclear copper cluster between domains 1 and 3, very similar to the arrangement found in other laccases [16,17]. E. coli $\mathrm{CueO}$ is a $53.4 \mathrm{kDa}$ periplasmic protein involved in the $\mathrm{Cu}$ efflux system and functions as the sole cupric oxidase responsible for the oxidation of cuprous ion to less toxic
C Biomed Central

() 2011 Li et al; licensee BioMed Central Ltd. This is an Open Access article distributed under the terms of the Creative Commons Attribution License (http://creativecommons.org/licenses/by/2.0), which permits unrestricted use, distribution, and reproduction in any medium, provided the original work is properly cited. 
cupric ion whilst coupling four one-electron substrate oxidation steps to the reduction of dioxygen to water through a T1-type copper at the substrate-binding site and a trinuclear copper center at the oxygen-binding site [1,19-21]. However, the recombinant $\mathrm{CueO}$ is much less active than many fungal laccases. Several groups have performed studies to understand the relationship between structure and function of $\mathrm{CueO}$, but as yet no clear conclusion has been reached up to date. Compared to fungal laccases, E106 perhaps decreases the microenvironmental hydrophobicity of the type II $\mathrm{Cu}$, replacement of E106 by a phenylalanine (Phe) found at the corresponding site of fungal laccases slightly increases the oxidase activity of CueO [22]. Different from fungal laccases, an extra $\alpha$-helix (L351-G378) near Cu I covers substrate binding pocket of CueO (see Figure 1). This $\alpha$-helix might compromise the electron transfer from substrate to type I copper in bacterial MCOs [19].

In our previous study, the gene encoding a $\mathrm{MCO}$ in a soil bacterium Klebsiella sp. 601 was cloned, the enzyme, with a mass of $58.2 \mathrm{kDa}$ was purified and a preliminary survey of the enzymatic properties of the recombinant MCO was carried out [15]. The amino acid sequence of Klebsiella sp. $601 \mathrm{MCO}$ is highly homologous to that of $E$. coli $\mathrm{CueO}$ with a similarity of $90 \%$ and a $78 \%$ identity. High homology in amino acid sequences indicates two enzymes are likely to share essentially the same three-dimensional molecular structure. In this study, five mutants have been made via either amino acid deletion or replacement at E106 and the $\alpha$-helix (L351-G378) region. Apart from three mutants expressing as inactive inclusion bodies, the mutants E106F and $\alpha 351-380 \mathrm{M}$ with oxidase activities have been purified and studied enzymatically. Compatible with the result obtained in E. coli CueO, replacement of E106 by a Phe in Klebsiella sp. 601 MCO suggests that E106 is not the only factor affecting the copper binding. Alteration of amino acid residue in the mutant $\alpha 351-380 \mathrm{M}$ changes the secondary structure of the $\alpha$-helix, and significantly improves oxidase activity towards phenolic substrate DMP.

\section{Results}

\section{Overexpression and purity of mutant enzymes}

Five mutated genes in the expression vector pET23a were separately transformed into E. coli BL21(DE3)pLysS to overproduce the respective mutant enzymes. In each case, E. coli transformants containing the pET23a recombinant plasmid with the mutated gene were cultured at $37^{\circ} \mathrm{C}$ in LB broth supplemented with $100 \mu \mathrm{g} / \mathrm{ml}$ ampicillin and then induced for 5 hours with $0.5 \mathrm{mM}$ IPTG. A $15 \%$ SDS-PAGE showed abundant overproduction of all mutant enzymes, approximately equivalent to that seen with cloned wild-type enzyme under otherwise identical conditions. Unfortunately, the majority of overproduction was in pellets as inactive inclusion bodies, and only the wild-type and E106F enzymes showed about 10\% and 5\% soluble protein in supernatants. In order to obtain more soluble enzyme, temperatures for bacterial cultivation were optimized. When five transformants were cultured at $23^{\circ} \mathrm{C}$, the mutants $\alpha 351-380 \mathrm{M}, \mathrm{E} 106 \mathrm{~F}$ and the wild type showed about 5-15\% soluble enzyme, whilst the other mutants ${ }^{\Delta} \alpha 351-378, \mathrm{E} 106 \mathrm{~F} /{ }^{\Delta} \alpha 351-378$ and E106F/ $\alpha 351-380 \mathrm{M}$ still showed no visible band of over-produced protein in supernatants on 15\% SDS gel. Table 2 summarizes overproduction of the five mutants and wildtype enzyme. All proteins in pellets and the crude extracts from three of the mutants, ${ }^{\Delta} \alpha 351-378$, E106F/ $\Delta \alpha 351-378$ and E106F/ $\alpha 351-380 \mathrm{M}$, gave negative reaction in the activity staining assay on $10 \%$ native gel (data not shown). Figure 2a shows a 15\% SDS gel displaying overproduction of three mutants E106F, $\alpha 351-380 \mathrm{M}$ and $\mathrm{E} 106 \mathrm{~F} / \alpha 351-380 \mathrm{M}$ under incubation at $23^{\circ} \mathrm{C}$. The crude extract from the mutant E106F/ $3551-380 \mathrm{M}$ showed no obvious band at the expected position on the SDS gel, and also gave undetectable activity in the activity staining assay. Enzyme activities in crude extracts of five mutants and the wild-type were also measured spectrophotometrically, and the results are listed in Table 1.

A Ni-affinity column was used for purifying the mutant and wild-type enzymes to minimize the risk of CueO contamination from E. coli host cells. After purification by $\mathrm{Ni}$-affinity chromatography, the enzymes purified from the mutants E106F and $\alpha 351-380 \mathrm{M}$ and the wild-type MCO exhibited a single band on the SDS gel with a molecular mass of about $60 \mathrm{kDa}$, similar to that $(58.2 \mathrm{kDa})$ reported for wild-type enzyme [15] (see Figure 2b). About $15 \mathrm{mg}$ E106F, $8 \mathrm{mg}$ a351-380M and 20 mg wild-type pure enzymes were obtained respectively from $1 \mathrm{~L}$ cultures of $E$. coli BL21(DE3)pLysS transformants after the purification described.

\section{Comparison of kinetic parameters between two mutant enzymes and wild-type MCO}

Enzyme activities of two mutants and wild-type MCO were examined with a fixed concentration of DMP (1 $\mathrm{mM})$, ABTS $(0.5 \mathrm{mM})$ or SGZ $(0.01 \mathrm{mM})$ over a range of $\mathrm{pH}$ values: the optimal $\mathrm{pHs}$ for the catalysis of two mutants were pH5.0 for DMP, pH3.6 for ABTS and pH6.8 for SGZ. The wild-type enzyme also gave the highest activities at $\mathrm{pH} 5.0$ for DMP, pH3.0 for ABTS and pH6.8 for SGZ.

Kinetic parameters were estimated under the conditions described in the experimental section by varying the DMP (0.2-5.0 mM), ABTS (0.05-1.0 mM) and SGZ (0.6-20 $\mu \mathrm{M})$ concentrations. The results are summarized in Table 2. As compared to the wild type, the $K_{m}$ value of E106F for DMP at pH5.0 is 2.4-fold low and the $k_{\text {cat }}$ 


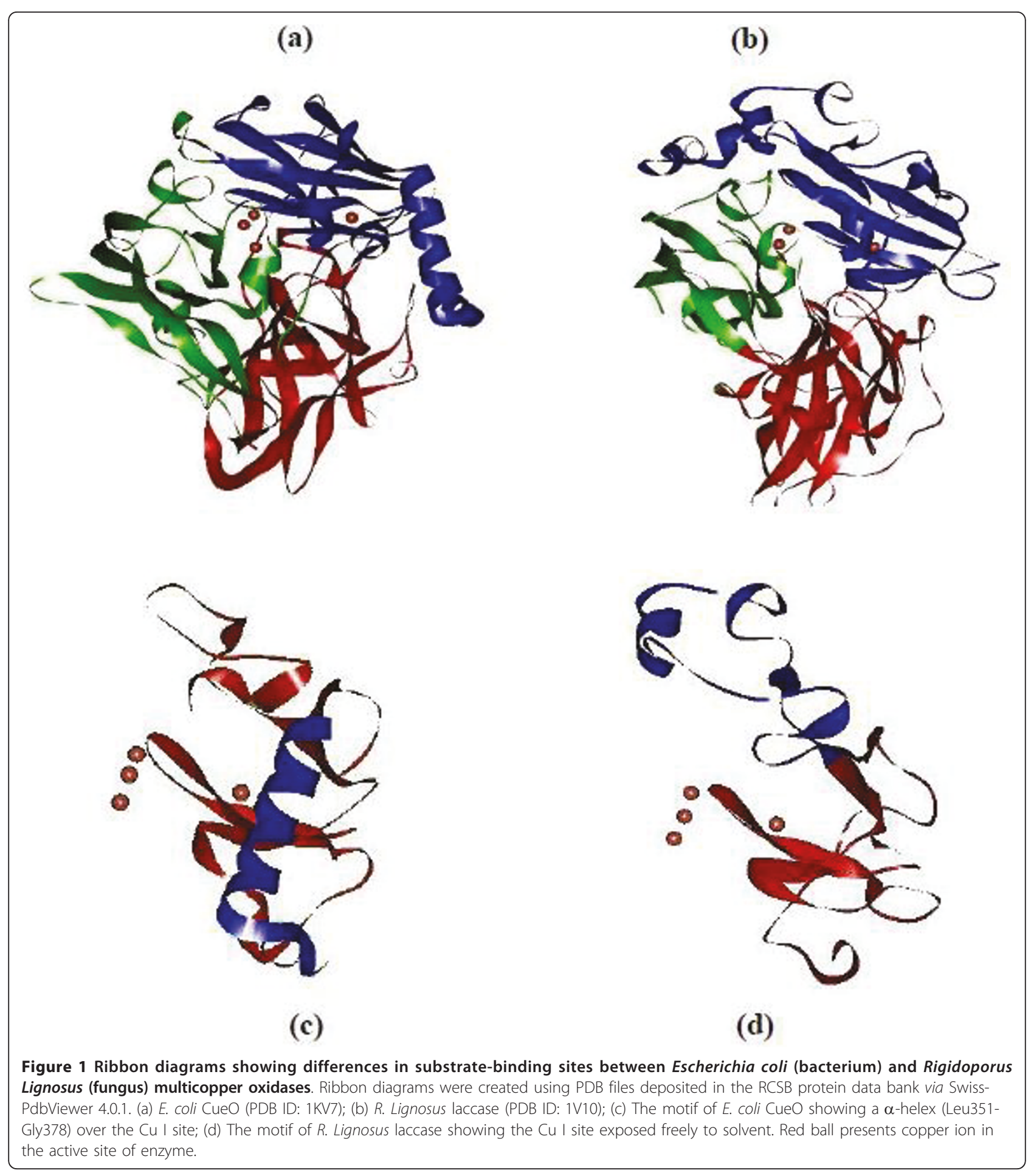

value remains comparable. The decreased $K_{m}$ value results in a 2.4-fold increase in the catalytic coefficient $\left(k_{c a t} / K_{m}\right)$ in mutant E106F. The $K_{m}$ value for the $\alpha 351$ $380 \mathrm{M}$ mutant is 4.5 -fold smaller, and the $k_{\text {cat }}$ and $k_{\text {cat }} /$ $K_{m}$ values are 2.1-fold and 9.4-fold larger respectively, as compared with those for the wild-type enzyme. The large catalytic coefficient with a low $K_{m}$ value indicates the mutant $\alpha 351-380 \mathrm{M}$ favors DMP as its substrate.

Kinetic parameters of two mutants for ABTS were also monitored at pH3.6. Both E106F and $\alpha 351-380 \mathrm{M}$ mutants gave the $K_{m}$ values of 159 and $284 \mu \mathrm{M}, 3.4-$ and 1.9-fold smaller than that $(539 \mu \mathrm{M})$ for the wild- 
Table 1 Protein expression of Klebsiella sp. 601 MCO and 5 mutants in $E$. coli

\begin{tabular}{|c|c|c|c|}
\hline Mutation & $\begin{array}{l}\text { Expression } \\
\text { in E.coli }\end{array}$ & $\begin{array}{l}\text { Active in } \\
\text { supernatant }\end{array}$ & $\begin{array}{l}\text { Protein in } \\
\text { pellet }\end{array}$ \\
\hline Wild type & + & + & + \\
\hline E106F & + & + & ++ \\
\hline${ }^{\Delta} \alpha 351-378$ & + & - & ++++ \\
\hline $\mathrm{E} 106 \mathrm{~F} /{ }^{\wedge} \alpha 351-378$ & + & - & ++++ \\
\hline a351-380M & + & + & +++ \\
\hline E106F/a351-380M & + & - & ++++ \\
\hline
\end{tabular}

Enzyme activity in supernatant was measured at $37^{\circ} \mathrm{C}$ by recording the change in $\mathrm{A}_{447}$ in $1 \mathrm{ml}$ assay mixture containing $1 \mathrm{mM} \mathrm{DMP}, 0.2 \mathrm{mM} \mathrm{CuSO}{ }_{4}$, $50 \mathrm{mM}$ acetic acid-sodium acetate (pH5.0) and $10 \mu \mathrm{l}$ crude extract. +: positive; -: negative.

type enzyme at pH3.0. Nevertheless, the catalytic coefficients for both mutants are very close to that for the wild-type enzyme due to their low $k_{c a t}$ values. Kinetic parameters for anther substrate SGZ were also estimated at pH6.8. Both mutants gave similar $K_{m}$ values for SGZ, 7-fold smaller than that for wild-type enzyme. However, again, $k_{\text {cat }} / K_{m}$ values for both mutants are only 1.7 - and 3-fold larger than that for the wild-type enzyme because of their low $k_{\text {cat }}$ values. Table 2 also shows that the wild-type enzyme, similar to the mutant E106F, catalyzes oxidation of ABTS much more effectively than the other two substrates DMP and SGZ. In contrast, the $\alpha 351-380 \mathrm{M}$ mutant uses DMP as effectively as ABTS based on the values of $k_{\text {cat }} / K_{m}$ obtained.

\section{Far-UV CD spectra of the two mutant enzymes}

In the mutant $\alpha 351-380 \mathrm{M}$, seven amino acid residues in the $\alpha$-helix region were altered to abolish the secondary structure of the $\alpha$-helix over the active pocket of the wild-type enzyme, based on the result of secondary
Table 2 Comparison of kinetic parameters for three laccase substrates between two mutants and wild type of Klebsiella sp. 601 MCO

\begin{tabular}{|c|c|c|c|}
\hline & Wild-type & E106F & $\alpha 351-380 M$ \\
\hline DMP & $\mathrm{pH} 5.0$ & $\mathrm{pH} 5.0$ & $\mathrm{pH} 5.0$ \\
\hline $\mathrm{K}_{\mathrm{m}}(\mu \mathrm{M})$ & $2,847 \pm 30$ & $1,176 \pm 47$ & $639 \pm 17$ \\
\hline $\mathrm{k}_{\text {cat }}\left(\mathrm{s}^{-1}\right)$ & $37,800 \pm 32$ & $37,480 \pm 886$ & $79,913 \pm 944$ \\
\hline $\mathrm{k}_{\mathrm{cat}} / \mathrm{K}_{\mathrm{m}}\left(\mu \mathrm{M}^{-1} \mathrm{~s}^{-1}\right)$ & 13.27 & 31.87 & 125.06 \\
\hline ABTS & $\mathrm{pH} 3.0$ & $\mathrm{pH} 3.6$ & pH3.6 \\
\hline$K_{m}(\mu M)$ & $539 \pm 5.0$ & $159 \pm 1.0$ & $284 \pm 6.2$ \\
\hline $\mathrm{k}_{\text {cat }}\left(\mathrm{s}^{-1}\right)$ & $68,409 \pm 342$ & $32,595 \pm 152$ & $35,990 \pm 704$ \\
\hline $\mathrm{k}_{\text {cat }} / \mathrm{K}_{\mathrm{m}}\left(\mu \mathrm{M}^{-1} \mathrm{~s}^{-1}\right)$ & 126.9 & 205.0 & $35,990 \pm 704$ \\
\hline SGZ & pH6.8 & pH6.8 & $\mathrm{pH} 6.8$ \\
\hline $\mathrm{K}_{\mathrm{m}}(\mu \mathrm{M})$ & $11.67 \pm 0.2$ & $1.57 \pm 0.02$ & $1.46 \pm 0.02$ \\
\hline $\mathrm{k}_{\text {cat }}\left(\mathrm{s}^{-1}\right)$ & $10.8 \pm 0.1$ & $2.43 \pm 0.02$ & $4.3 \pm 0.05$ \\
\hline $\mathrm{k}_{\text {cat }} / \mathrm{K}_{\mathrm{m}}\left(\mu \mathrm{M}^{-1} \mathrm{~s}^{-1}\right)$ & 0.93 & 1.5 & 2.95 \\
\hline
\end{tabular}

All data obtained from three independent experiments are presented as the mean of Michaelis-Menten parameters with the standard deviation (SD). Detailed measurements and data analysis were performed as described in Experimental section.

structure prediction by the program PROF (http://www. aber.ac.uk/ phiwww/prof). PROF predicted that the mutation R361G/M362G./L367G/M368G/E369P/ M376K/M379P could abolish $\alpha$-helix structure at the a351-378 region. Figure 3 shows the detailed changes in both DNA and amino acid sequences of the mutant $\alpha 351-380 \mathrm{M}$. Although the program PROF predicted the $\alpha$-helix structure the $\alpha 351-378$ region could unfold when the seven amino acid residues were substituted by those amino acids described, it needed to be tested whether this $\alpha$-helix really vanished. To solve this issue, the far-UV CD spectra of two mutants and wild-type enzymes were recorded at $20^{\circ} \mathrm{C}$ in $0.1 \mathrm{M}$ potassium phosphate (pH7.0), and the secondary structure content

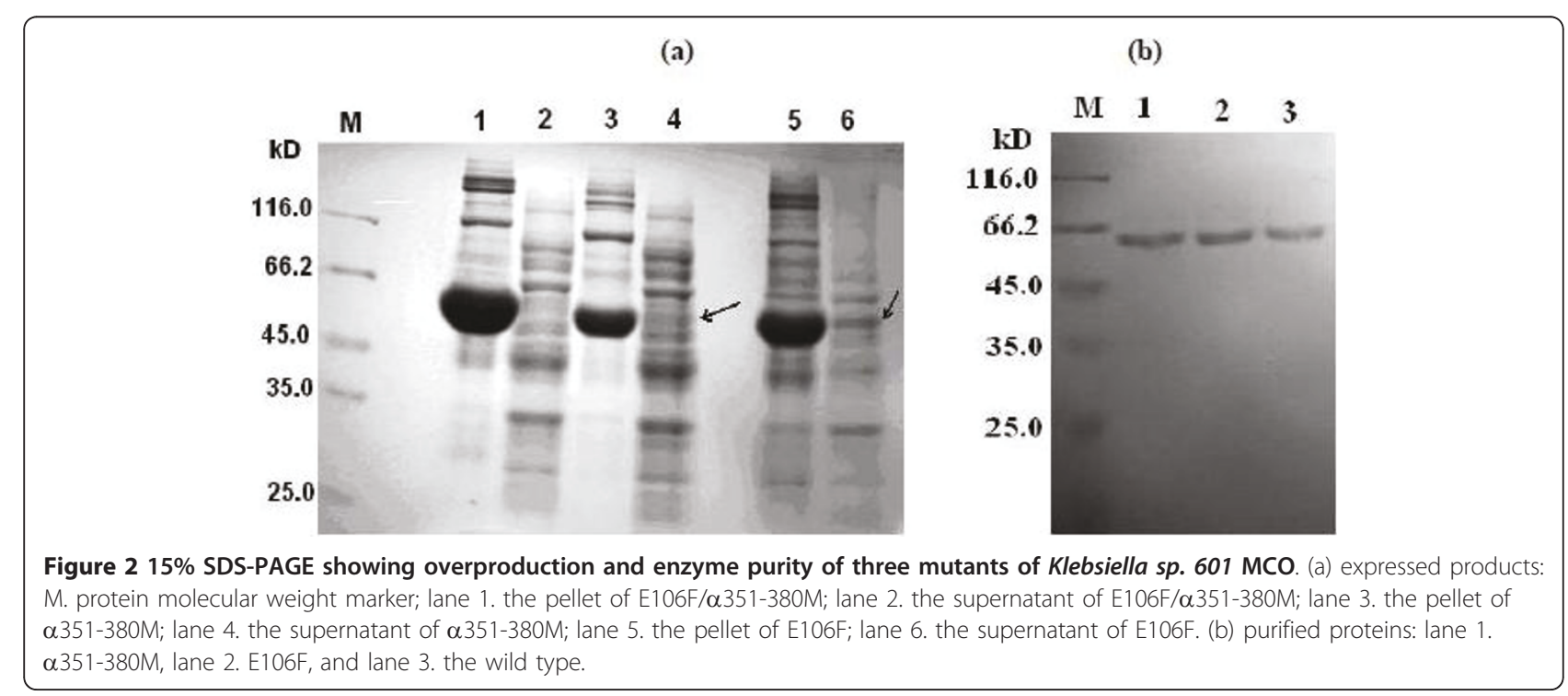




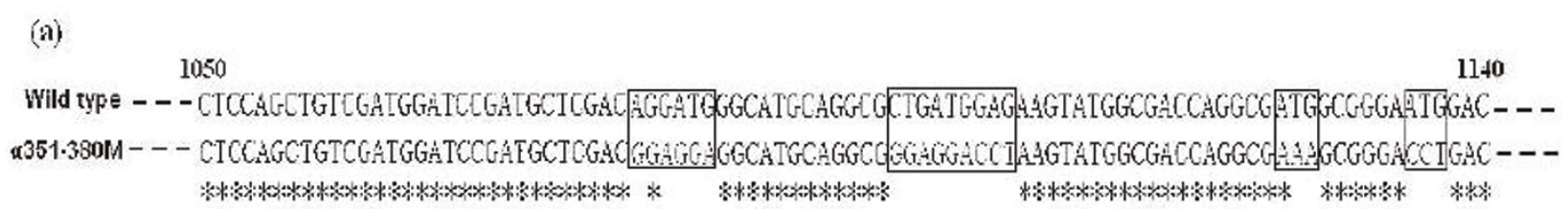

(b)

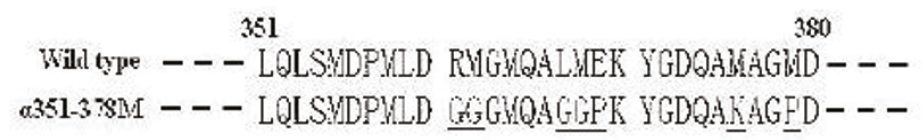

Figure 3 Sequence comparison between the mutant $\alpha 351-380 \mathrm{M}$ and the wild-type MCO. (a) Nucleotide sequences; (b) Amino acid sequences. Those bases mutated in DNA sequence are framed and the corresponding amino acids changed in amino acid sequence are underlined.

of each protein was estimated using the program JASCOW32. The far-UV CD spectrum at 208-228 $\mathrm{nm}$ for the $\alpha 351-380 \mathrm{M}$ mutant was markedly less intense than that for the wild-type enzyme, while that of the point mutant E106F was essentially identical to the spectrum of the wild-type (Figure 4). The secondary structure prediction by the program JASCOW32 gave $16.9 \% \alpha$-helex, $23 \% \beta$-sheet, $29.7 \% \beta$-turn and $30.4 \%$ random coil for the wild-type enzyme, $17.1 \% \alpha$-helex, $22.8 \% \beta$-sheet, $30 \% \beta$-turn and $30.1 \%$ random coil for the mutant E106F, and 15.6\% $\alpha$-helex, 24.1\% $\beta$-sheet, 30.1\% $\beta$-turn and $30.2 \%$ random coil for the mutant $\alpha 351-380 \mathrm{M}$. CD spectrum analysis thus indicates that the E106F mutant may have similar secondary structure to the wild-type enzyme, whereas the replacement of seven amino acids in the $\alpha 351-380 \mathrm{M}$ mutant appears to change $\alpha$-helix structure as predicted by the computer program PROF.

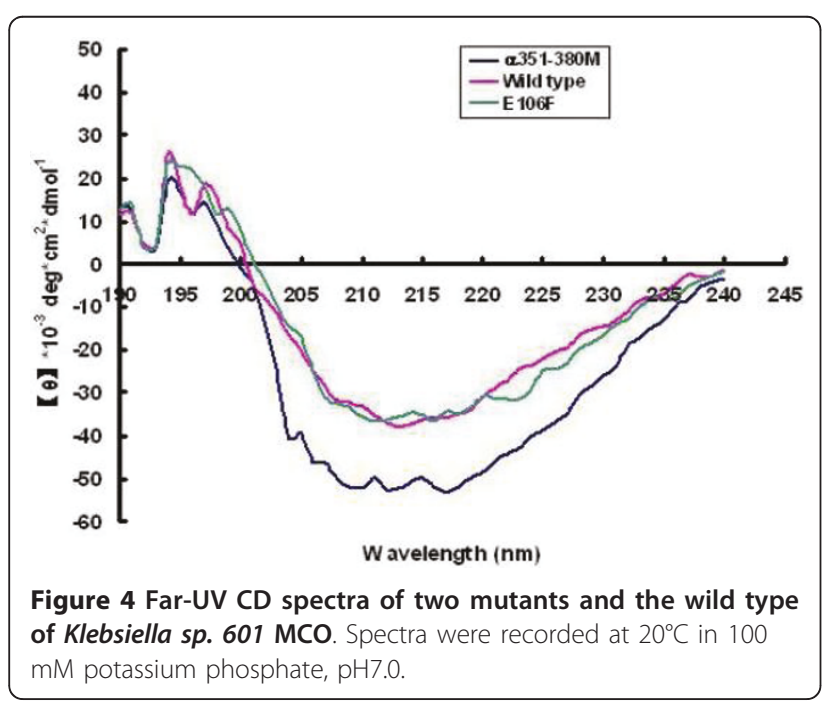

\section{Discussion}

Based on the information up to date, bacterial multicopper oxidases possess much lower oxidative activities compared to fungal laccases, although structure comparison between bacterial and fungal laccases shows the overall structure and copper coordination are very similar. Nevertheless, a charged residue Glu (E106) in CueO replaces the corresponding residue Phe in fungal laccases at the gate of the tunnel connecting type II copper to the protein surface [19]. Li et al (2007) have suggested the hydrophobic residue Phe in fungal laccases likely gates the tunnel and prevents type II copper exchange from solvent, while the charged residue Glu in CueO would make type II copper solvent accessible and easy to be lost [22]. According to this hypothesis, replacement of E106 by a Phe residue should enhance oxidase activities of Klebsiella sp. 601 MCO. Kinetic data collected from individual enzyme assay towards DMP, ABTS or SGZ shows that the E106F mutant has smaller $K_{m}$ and $k_{\text {cat }}$ values but larger $k_{\text {cat }} / K_{m}$ values for all three substrates as compared with those for the wild-type enzyme (see Table 2). Its larger $k_{\text {cat }} / K_{m}$ values for three substrates, which mainly comes from its small $K_{m}$, indicate the mutant E106F catalyzes DMP, ABTS or SGZ more effectively than the wild-type enzyme. Although the $K m$ value may not really represent binding constant for its substrate to an enzyme, smaller $K_{m}$ values for three substrates imply that E106 is not to be the only factor affecting the copper binding. Given that E106 is far from the substrate binding site, it is difficult to explain why E106F should have decreased $K_{m}$ values for all three substrates. Easy access of three substrates to the $\mathrm{Cu}$ I site in the active pocket may imply a possibly conformational change of this active pocket in the mutant enzyme. This may also offer us an explanation for the combined mutant E106F/ $\alpha 351-380 \mathrm{M}$ expressed in E. coli as inactive inclusion body owing to improper folding. 
In the proposed mechanism of laccase catalysis, electrons are first transported from substrate to type I copper, and then travel through a $13 \AA$ pathway formed by a cysteine and two histidines to type III copper, and finally reduce molecular oxygen to water at type II copper [23]. According to this mechanism, substrates should bind near the type I copper. In the molecular model of the complex of B. subtilis CotA and substrate, the ABTS-binding pocket is indeed very close to the type I copper site [16]. Kataoka et al (2007) also noticed that the substrate-binding site of $\mathrm{CueO}$ is buried deeply under a methionine-rich helical region including $\alpha$ helices 5, 6 and 7, which is different from other MCOs [24]. They deleted the methionine-rich region Pro357His406 and then replaced it with a Gly-Gly linker. The cuprous oxidase activity of the truncated mutant decreases to $10 \%$ that of the wild-type enzyme, but the activities for laccase substrates ABTS and DMP are very similar in the presence of $\mathrm{Cu}(\mathrm{II})$ ions [24]. 50 amino acid residues replaced by a Gly-Gly linker may perhaps result in too much flexibility of the peptide chain containing rich Gly residues in solvent so that substrates may not easily gain access to the active pocket of the mutated enzyme. Detailed structural comparison has shown that the substrate binding pockets in fungal laccases are fully open and type I copper is exposed to solvent. In contrast, in the bacterial CueO, an extra $\alpha$-helix (L351-G378) is located over type I copper and makes the substrate binding pocket smaller [19]. To test this hypothesis in the present study, a mutant ${ }^{\Delta} \alpha 351-378$ was first created by deleting 28 amino acids of the $\alpha$ helix. The mutated protein was expressed in the form of inactive inclusion bodies in the pellet, similar to the result obtained in E. coli CueO [19]. The deletion of $\alpha$ helix may result in improper folding of the ${ }^{\Delta} \alpha 351-378$ mutant. To further examine if the $\alpha$-helix from L351 to G378 affects substrate binding, the mutant $\alpha 351-380 \mathrm{M}$ was made through substitution of seven amino acid residues in the $\alpha$-helix. Far-UV CD spectrum suggests that the replacement of seven amino acids appears to abolish the secondary structure of the $\alpha$-helix between L351 G378. The $\alpha 351-380 \mathrm{M}$ mutant is active towards all three substrates tested with very small $K_{m}$ values, 2-7 fold lower than those for the wild-type enzyme (see Table 2). Decreased $K_{m}$ values indicate that the $\alpha$-helix from L351 to G378 indeed is a barrier for substrate binding to the enzyme. As compared to the wild-type enzyme, the $\alpha 351-380 \mathrm{M}$ mutant gives a 2-fold lower $k_{\text {cat }}$ with a similar $k_{\text {cat }} / K_{m}$ values for ABTS, a 2 -fold lower $k_{\text {cat }}$ with a 3 -fold larger $k_{\text {cat }} / K_{m}$ value for SGZ, and a 2 -fold larger $k_{\text {cat }}$ with a 10 -fold larger $k_{\text {cat }} / K_{m}$ value for DMP. Smaller $K_{m}$, larger $k_{\text {cat }}$ and $k_{\text {cat }} / K_{m}$ for DMP demonstrate that structural modification at $\alpha 351$ 378 markedly enhances oxidase activity of Klebsiella $s p$.
$601 \mathrm{MCO}$ towards phenolic substrate DMP. The wildtype MCO favors ABTS as substrate, whereas the $\alpha 351$ $380 \mathrm{M}$ mutant catalyzes the substrate DMP as effectively as ABTS, demonstrating that the $\alpha 351-378$ shifts its substrate specificity towards DMP. Our results suggest the $\alpha$-helex may also play a role in substrate specificities of bacterial MCOs.

Laccases are very attractive enzymes for application in biotechnology and green chemistry. At present, only fungal laccases are used in industrial processes. However, fungal laccases are much more difficult to express as active enzymes in bacterial or yeast hosts to meet industrial requirement. Bacterial laccases perhaps are another candidate for industry. 10-fold increase of substrate specificity offers an opportunity to use the $\alpha 351$ $380 \mathrm{M}$ mutant for biotechnological application. Its low soluble expression in $E$. coli will be improved in the near future by periplasmic protein expression, random mutagenesis or incubating under low temperature plus microaerobic conditions, because these strategies have been recently demonstrated to be a very useful in $B$. licheniformis and Bacillus sp. HR03 CotA [25,26]. The a351-380M mutant is an example of the successful modification of MCO function to a large extent, and extensive engineering of bacterial laccases is expected to create more novel functions.

\section{Conclusion}

In summary, the data obtained from kinetic analysis of two mutants shows that (1) the glutamate residue at position 106 appears not to be the only factor affecting the copper binding, and it may also play a role in maintaining enzyme conformation correctly; and (2) the $\alpha$ helix (L351-G378) may not only block access to the type I copper site but also play a role in substrate specificities of bacterial MCOs. The $\alpha 351-380 \mathrm{M}$ mutant catalyzing oxidation of the phenolic substrate DMP effectively would be very useful in green chemistry.

\section{Materials and methods}

\section{Materials and chemicals}

KOD plus taq DNA polymerase, dNTP and Dpn1 were obtained from Takara and Toyoba (Japan). Laccase substrates 2,6-dimethylphenol (MDP), 2,2'-azino-bis-(3ethylbenzibiozoline 6-sulfonic acid) (ABTS) and 4hydroxy-3,5- dimethoxybenzaldehyde azine (SGZ) were acquired from Sigma (USA). Oligonucleotides for mutagenesis and DNA sequencing were made by Invitrogen (Shanghai). All chemicals were of analytical grade.

\section{Bacterial strains and vectors}

The E. coli strains used in mutagenesis and gene expression were $\mathrm{DH} 5 \alpha$ ( $\mathrm{F}^{-}$endA1 glnV44 thi-1 recA1 relA1 gyrA96 deoR nupG \$80dlacZ $\Delta$ M15 $\Delta$ (lacZYA-argF) 
U169, hsdR17 $\left.\left(\mathrm{r}_{\mathrm{K}}^{-} \mathrm{m}_{\mathrm{K}}^{+}\right), \lambda^{-}\right)$and BL21(DE3)pLysS ( $\mathrm{F}^{-}$ ompT gal dcm lon hsdS $\left.\mathrm{B}_{\mathrm{B}}\left(\mathrm{r}_{\mathrm{B}}{ }^{-} \mathrm{m}_{\mathrm{B}}{ }^{-}\right) \lambda(\mathrm{DE} 3) \mathrm{pLysS}\left(\mathrm{cm}^{\mathrm{R}}\right)\right)$, both from Promega Biotech Co. The recombinant plasmid pET23a-601 harbouring Klebsiella sp. $601 \mathrm{MCO}$ gene was constructed by Ms. Jiao Yin.

\section{Mutagenesis of Klebsiella sp. 601 MCO gene}

Standard procedures [27] were used for extracting the plasmid pET23a-601 from the host strain E. coli DH5 $\alpha$, and transforming the plasmid DNA into E. coli DH5 $\alpha$ for DNA amplification or E. coli BL21(DE3)pLysS for overexpression of the mutant enzymes. The strategy for mutagenesis, developed by Li et al (2008) [28], was modified and used for both base substitution and DNA deletion. The plasmid pET23a-601 DNA was used as a template, and the primers for mutagenesis (see table 3 ) were used for DNA amplification in the presence of KOD plus Taq DNA polymerase, $\mathrm{MgCl}_{2}$ and dNTP. The PCR reaction was initiated by preheating the reaction mixture at $94^{\circ} \mathrm{C}$ for $4 \mathrm{~min}$, followed by 30 cycles of denaturation at $94^{\circ} \mathrm{C}$ for $15 \mathrm{~s}$, annealing and extension at $68^{\circ} \mathrm{C}$ for $5 \mathrm{~min}$ with a final extension at $68^{\circ} \mathrm{C}$ for $8 \mathrm{~min}$. To create the mutant a351-380M, two rounds of PCR were performed. In the first round, the plasmid pET23a-601 DNA, the oligonucleotides $\alpha 351-380 \mathrm{M}-\mathrm{F} 1$ and $\alpha 351-380 \mathrm{M}-\mathrm{R} 1$ were used as the template and primers for DNA amplification. In the second round, the plasmid DNA recovered from the first round of PCR was used as a template, and the oligonucleotides $\alpha 351-380 \mathrm{M}-\mathrm{F} 2$ and $\alpha 351-380 \mathrm{M}-\mathrm{R} 2$ were used as primers. imilar strategies were used to create E106F/ ${ }^{\Delta} \alpha 351-378$ and E106F/ $3351-380 \mathrm{M}$ via two or three rounds of PCR. The PCR-amplified DNA was separated by $0.7 \%$ agarose gel, recovered using the gel recovery kit (V-gene) and then digested with $D p n \mathrm{I}$ at $37^{\circ} \mathrm{C}$ for 2 hours. The DpnI-digested DNA was transformed into E. coli DH5 $\alpha$ via the calcium chloride method [27], and positive colonies were selected at $37^{\circ} \mathrm{C}$ on the overnight-cultivated LB plates containing $100 \mu \mathrm{g} / \mathrm{ml}$ ampicillin. All mutants were screened and confirmed directly by DNA sequencing of the mutant genes.
In this study, five mutants were finally obtained through one, two or three rounds of PCR and DpnI digestion as described above. In the mutant E106F, the phenylalanine codon (TTT) replaced the wild-type glutamate (GAG). To investigate if the $\alpha$-helix (L351-G378) affects substrate access to the type I copper site, the mutant $\Delta \alpha 351-378$ was first created by deleting all 28 amino acids in the $\alpha 351-378$ region of wild-type enzyme. Then the mutant $\alpha 351-380 \mathrm{M}$ was also made via substitution of $361 \mathrm{R}, 362 \mathrm{M}, 367 \mathrm{~L}, 368 \mathrm{M}, 369 \mathrm{E}$, $376 \mathrm{M}, 379 \mathrm{M}$ with a glycine, glycine, glycine, glycine, proline, lysine and proline, respectively. The point mutant E106F was also combined with the mutant ${ }^{\Delta} \alpha 351-378$ and $\alpha 351-380 \mathrm{M}$ to form two other mutants E106F $/{ }^{\Delta} \alpha 351-378$ and E106F/ $\alpha 351-380 \mathrm{M}$. All mutations were confirmed by sequencing the overall DNA of each mutated gene.

\section{Enzyme preparation}

The recombinant plasmids with the mutated $\mathrm{MCO}$ genes were extracted from E. coli DH5 $\alpha$, and then transformed into E. coli BL21(DE3)pLysS. Positive transformants of E. coli BL21(DE3)pLysS were grown at $23^{\circ} \mathrm{C}$ in $\mathrm{LB}$ broth containing $100 \mu \mathrm{g} / \mathrm{ml}$ ampicillin and induced by adding $0.5 \mathrm{mM}$ isopropyl $\beta$-D-thiogalactopyranoside (IPTG) into the culture when $\mathrm{OD}_{600}$ was equal to 0.6. Bacterial cells were harvested and sonicated, and crude extracts were prepared through centrifugation at 27,000 $\mathrm{g}$ for $15 \mathrm{~min}$.

Each mutant enzyme was purified by Ni-affinity chromatography, as described for the cloned wild-type MCO [15]. The clarified crude extract was loaded onto the $\mathrm{Ni}$ column equilibrated with $100 \mathrm{mM}$ phosphate (pH7.4). The column was washed with $100 \mathrm{mM}$ phosphate (pH7.4) and then eluted with a gradient of 20-150 mM imidazole in $100 \mathrm{mM}$ phosphate (pH7.4). Fractions were collected automatically with $1 \mathrm{ml}$ per tube. Enzyme purity was routinely examined by SDS-PAGE on $15 \%$ gels, and the concentration of purified enzyme was estimated from $\mathrm{A}_{280}$ on the basis of the absorption coefficient of

Table 3 Oligonucleotide primers used for mutating Klebsiella sp. 601 MCO gene

\begin{tabular}{|c|c|}
\hline Oligo name & Sequence \\
\hline 106F-F & 5'-ACTGGCATGGCCTGTTTTGTCCCGGGCGAGGTC-3' \\
\hline 106F-R & 5'-CCTCGCCCGGGACAAACAGGCCATGCCAGTG -3' \\
\hline$\Delta \alpha 351-378-F$ & 5'- GGGCTGACGCAGCGTCAGATGGACCACGGCATGATGGA -3' \\
\hline${ }^{\Delta} \alpha 351-378-R$ & $5^{\prime}-$-CTGACGCTGCGTCAGCCCCGTCAGGGACGGT -3' \\
\hline$\alpha 351-380 M-F 1$ & 5'-GATCCGATGCTCGACGGAGGAGGCATGCAGGCGGGAGGACCTAAGTATGGC GACCAG-3' \\
\hline$\alpha 351-380 M-R 1$ & 5'-CTGGTCGCCATACTTAGGTCCTCCCGCCTGCATGCCTCCTCCGTCGAGCAT CGGATC-3 \\
\hline$\alpha 351-380 M-F 2$ & 5'-TATGGCGACCAGGCGAAAGCGGGACCTGACCACGGCATGATG -3' \\
\hline$\alpha 351-380 M-R 2$ & 5'-CATCATGCCGTGGTCAGGTCCCGCTTTCGCCTGGTCGCCATA -3' \\
\hline
\end{tabular}

* Underlining indicates the sequences pairing between the forward and reverse primers for the deletion of $\alpha 351-378$. Mismatch bases are bold in each oligonucleotide. 
$1.03 \mathrm{mg} \mathrm{ml}^{-1}$ predicted by the program ProtParam (http://expasy.org/tools/protparam.html). The pure enzyme, precipitated in $65 \%$ ammonium sulfate and stored at $4^{\circ} \mathrm{C}$, was dialyzed before use against several changes of $100 \mathrm{mM}$ phosphate buffer (pH7.4), and clarified by centrifugation.

\section{Enzyme assays}

Enzyme activity in crude extract was initially examined using activity staining on $10 \%$ native gel, as described by Li et al [15]. The gel was first soaked in $50 \mathrm{mM}$ acetate buffer (pH5.0) for $10 \mathrm{~min}$, and then stained in $2.5 \mathrm{mM}$ DMP, $0.2 \mathrm{mM} \mathrm{CuSO}_{4}$ and $50 \mathrm{mM} \mathrm{H} \mathrm{H}_{3} \mathrm{PO}_{4}-\mathrm{Na}_{2} \mathrm{HPO}_{4}$ (pH5.0) at room temperature for 10-15 min. Enzyme activity was also examined spectrophotometrically at $37^{\circ}$ $\mathrm{C}$ by recording the change in $\mathrm{A}_{447}$ in the assay mixture containing $1 \mathrm{mM}$ DMP, $0.2 \mathrm{mM} \mathrm{CuSO}_{4}, 50 \mathrm{mM}$ acetic acid-sodium acetate (pH5.0) and $10 \mu \mathrm{l}$ crude extract.

Specific activity was measured with a Shimadzu UV/ visible spectrophotometer (UV-2550). The extinction coefficients used in active assays were $14.8 \mathrm{mM}^{-1} \mathrm{~cm}^{-1}$ for DMP, $36 \mathrm{mM}^{-1} \mathrm{~cm}^{-1}$ for ABTS and $65 \mathrm{mM}^{-1} \mathrm{~cm}^{-1}$ for SGZ. Oxidation of DMP was assayed at $37^{\circ} \mathrm{C}$ in 50 $\mathrm{mM}$ acetate (pH5.0), of ABTS in $50 \mathrm{mM}$ acetic acidsodium acetate (pH3.0 or 3.6), and of SGZ in $50 \mathrm{mM}$ phosphate (pH6.8). In addition, $0.2 \mathrm{mM} \mathrm{CuSO}_{4}$ was routinely added into the reaction solution. Specific activities were expressed as units of activity per milligram of protein, where one unit represented a micromole of substrate oxidized per minute. To determine kinetic parameters, rates were measured spectrophotometrically at $37^{\circ} \mathrm{C}$ with $0.2 \mathrm{mM} \mathrm{CuSO}_{4}$ over a range of substrate concentrations (for DMP 0.2-5.0 mM, ABTS 0.05-1.0 $\mathrm{mM}$ and SGZ 0.6-20 $\mu \mathrm{M})$. Michaelis-Menten parameters were calculated using the UVProbe-[Kinetics] version 1.11a (SHIMADZU Corporation), and kinetic parameters were determined by Lineweaver-Burk plot [29] and also checked by Hanes-Woolf and Eddie-Hofstee plots. The deviation between the same parameters obtained from different plots was less than $5 \%$. In each plot, correlation coefficient $\left(\mathrm{r}^{2}\right)$ value was equal to or large than 0.997. All data were also analyzed using the statistic software SPSS based on the non-linear regression method INVERSE, and analysis of variance gave $\mathrm{P}$ values of less than 0.005 in each case.

\section{Acknowledgements}

We thank Prof. Paul C Engel of Conway Institute, University College Dublin, Republic of Ireland, for his helps with review of the manuscript and English editing, and Mr. Wenfeng Zuo for his kindly technical supports. These studies were financially supported by Hubei Provincial Department of Education (2004Z001 to XGW) and Wuhan Science and Technology Bureau (201160823257 to YL).

\section{Authors' contributions}

All authors read and approved the final manuscript. X-GW conceived the study; $Y L, Z G$ and $X L$ contributed to the design of the study; $Y L, Z G$ and $X L$ performed the experiments and analyzed the results; $X-G W$ and $Z G$ wrote the paper.

Received: 3 January 2011 Accepted: 31 May 2011

Published: 31 May 2011

\section{References}

1. Solomon El, Sundaram UM, Machonkin TE: Multicopper Oxidases and Oxygenases. Chem. Rev 1996, 96:2563-2606.

2. Baldrian P: Fungal. laccases - occurrence and properties. FEMS Microbiol Rev 2006, 30:215-42.

3. Sharma P, Goel R, Capalash N: Bacterial laccases. World J Microbiol Biotechnol 2007, 23:823-832.

4. Leonowicz A, Cho NS, Luterek J, Wilkolazka A, Wojtas-Wasilewska M, Matuszewska A, Hofrichter M, Wesenberg D, Rogalski J: Fungal laccase: properties and activity on lignin. J Basic Microbiol 2001, 41:185-227.

5. Bajpai P: Application of enzymes in the pulp and paper industry. Biotechnol Prog 1999, 15:147-57.

6. Claus H, Faber $\mathrm{G}$, König H: Redox-mediated decolorization of synthetic dyes by fungal laccases. Appl. Microbiol Biotechnol 2002, 59:672-678.

7. Mohandass C, Knutson K, Ragauskas AJ: Laccase treatment of recycled blue dyed paper: physical properties and fiber charge. J Ind Microbiol Biotechnol 2008, 35:1103-1108.

8. Galante YM, Formantici C: Enzyme Applications in Detergency and in Manufacturing Industries. Current Organic Chemistry 2003, 7:1399-1422.

9. Pointing S: Feasibility of bioremediation by white-rot fungi. Appl. Microbiol Biotechnol 2001, 57:20-33.

10. Majeau J, Brar SK, Tyagi RD: Laccases for removal of recalcitrant and emerging pollutants. Bioresource Technology 2010, 101:2331-2350.

11. Molina-Guijarro JM, Pérez J, Muñoz-Dorado J, Guillén F, Moya R, Hernández M, Arias ME: Detoxification of azo dyes by a novel pHversatile, salt-resistant laccase from Streptomyces ipomoea. Int Microbiol 2009, 12:13-21.

12. Ruijssenaars HJ, Hartmans S: A cloned Bacillus halodurans multicopper oxidase exhibiting alkaline laccase activity. Appl Microbiol Biotechnol 2004, 65:177-182.

13. Koschorreck K, Richter SR, Ene AB, Roduner E, Schmid RD, Urlacher VB: Cloning and characterization of a new laccase from Bacillus licheniformis catalyzing dimerization of phenolic acids. Appl Microbiol Biotechnol 2008, 79:217-224.

14. Sharma P, Goel R, Capalash N: Bacterial laccases. World J Microbiol Biotechnol 2007, 23:823-832.

15. Li Y, Yin J, Qu G, LV L, Li Y, Yang S, Wang XG: Gene cloning protein purification and enzymatic properties of multicopper oxidase from Klebsiella sp. 601. Can J. Microbiol 2008, 54:725-733.

16. Enguita FJ, Martins LO, Henriques AO, Carrondo MA: Crystal structure of a bacterial endospore coat component. A laccase with enhanced thermostability properties. J Biol Chem 2003, 278:19416-19425.

17. Roberts SA, Weichsel A, Grass G, Thakali K, Hazzard JT, Tollin G, Rensing C, Montfort WR: Crystal structure and electron transfer kinetics of CueO, a multicopper oxidase required for copper homeostasis in Escherichia coli. PNAS 2002, 99:2766-2771.

18. Ska'lova' T, Dohna'lek J, Østergaard LH, Østergaard PR, Kolenko P, Dus`kova' J, Hašek J: Crystallization and preliminary X-ray diffraction analysis of the small laccase from Streptomyces coelicolor. Acta Cryst 2007, F63:1077-1079.

19. Rensing C, Grass G: Escherichia coli mechanisms of copper homeostasis in a changing environment. FEMS Microbiol. Rev 2003, 27:197-213.

20. Singh SK, Grass G, Rensing C, Montfort WR: Cuprous oxidase activity of CueO from Escherichia coli. J. Bacteriol 2004, 186:7815-7817.

21. Grass G, Thakali K, Klebba PE, Thieme D, Müller A, Wildner GF, Rensing C: Linkage between catecholate siderophores and the multicopper oxidase CueO in Escherichia coli. J. Bacteriol 2004, 186:5826-5833.

22. Li X, Wei Z, Zhang M, Peng X, Yu G, Teng M, Gong W: Crystal structures of E. coli laccase CueO at different copper concentrations. Biochem Biophys Res Commun 2007, 354:21-26. 
23. Solomon El, Sundaram UM, Machonkin TE: Multicopper Oxidases and Oxygenases. Chem Rev 1996, 96:2563-2606.

24. Kataoka K, Komori H, Ueki Y, Konno Y, Kamitaka Y, Kurose S, Tsujimura S, Higuchi Y, Kano K, Seo D, Sakurai T: Structure and function of the engineered multicopper oxidase $\mathrm{CueO}$ from Escherichia coli-deletion of the methionine-rich helical region covering the substrate-binding site. J Mol Biol 2007, 373:141-52.

25. Koschorreck K, Schmid RD, Urlacher VB: Improving the functional expression of a Bacillus licheniformis laccase by random and sitedirected mutagenesis. BMC Biotechnol 2009, 9:12.

26. Mohammadian M, Fathi-Roudsari M, Mollania N, Badoei-Dalfard A, Khajeh K: Enhanced expression of a recombinant bacterial laccase at low temperature and microaerobic conditions: purification and biochemical characterization. J Ind Microbiol Biotechnol 2010, 37:863-869.

27. Sambrook J, Fritsch EJ, Maniatis T: Molecular cloning: a laboratory manual. Cold Spring Harbor Laboratory Press, Cold Spring Harbor, N.Y., 32001.

28. Li J, Li C, Xia W, Yuan D, Wan G, Ma L: Site-directed mutagenesis by combination of homologous recombination and Dpnl digestion of the plasmid template in Escherichia coli. Analytical Biochemistry 2008, 373:389-391.

29. Lineweaver H, Burk D: The Determination of Enzyme Dissociation Constants. Journal of the American Chemical Society 1934, 56:658-666.

doi:10.1186/1471-2091-12-30

Cite this article as: Li et al:: Engineering Klebsiella sp. 601 multicopper oxidase enhances the catalytic efficiency towards phenolic substrates. BMC Biochemistry 2011 12:30.

\section{Submit your next manuscript to BioMed Central and take full advantage of:}

- Convenient online submission

- Thorough peer review

- No space constraints or color figure charges

- Immediate publication on acceptance

- Inclusion in PubMed, CAS, Scopus and Google Scholar

- Research which is freely available for redistribution

Submit your manuscript at www.biomedcentral.com/submit 